\title{
In-vitro Evaluation of Anti-microbial and Cytotoxic Activity of Artemisia judaica Leaves and Stem Extracts via Induction of Caspase Dependent Apoptosis
}

\author{
Kareem Mahmoud Younes 1,2, Mohamed Khaled Bin', Rahamat Unissa ${ }^{3}$, Afnan Abdulkarem \\ Almarshdi ${ }^{4}$, Fai Mutaz Alharbi ${ }^{4}$, Sulafa Salem Alenzi ${ }^{4}$, Bayan Naef albsher ${ }^{4}$, Amr Salah Abouzied ${ }^{1,5, *}$ \\ ${ }^{1}$ College of Pharmacy, Department of Pharmaceutical Chemistry, University of Hail, Hail, SAUDI ARABIA. \\ ${ }^{2}$ Faculty of Pharmacy, Department of Analytical Chemistry, Cairo University, Cairo, EGYPT. \\ ${ }^{3}$ College of Pharmacy, Department of Pharmaceutics, University of Hail, Hail, SAUDI ARABIA. \\ ${ }^{4}$ College of Pharmacy, University of Hail, Hail, SAUDI ARABIA. \\ ${ }^{5}$ National Organization for Drug Control and Research, Cairo, EGYPT.
}

\begin{abstract}
Medicinal plants and herbs are commonly used in the world to treat various human disorders. Artemisia judaica is one of these herbal species that is commonly used in medicine due to its contents of many bioactive compounds such as; flavonoids, lactones, essential oil and sesqui-terpenoids. It was used in many traditional medicines as an anthelmintic, antispasmodic, anti-rheumatic, and antibacterial agent. In recent years, anti-bacterial and anti-cancer activity of medicinal herbs are highly investigated. The present study is focused on the anti-microbial and cytotoxic effect of methanolic extract of Artemisia judaica leaves and stem. The antimicrobial assay was done on different gram-positive and gram-negative bacteria and it was revealed that leaves and stem extracts possess high and moderate activity against Staphylococcus aureus (MIC $312.5 \mu \mathrm{g} / \mathrm{ml}$ and $625 \mu \mathrm{g} / \mathrm{ml}$ ) and Proteus vulgaris (MIC $312.5 \mu \mathrm{g} / \mathrm{ml}$ and $1250 \mu \mathrm{g} / \mathrm{ml}$ ) for leaves and stem, respectively. Extracts were screened against HepG2, HCT-116, MCF-7, A-549 and MRC-5 cancer cells and it was found that both extracts were active against all cell lines with highest selectivity and cytotoxic activity observed against HepG2 cells (IC ${ }_{50}=3.38$ and $6.84 \mu \mathrm{g} / \mathrm{ml}$, for leaves and stem respectively). Further mechanistic studies on HepG2 cells showed that both extracts resulted in S-phase arrest and induced apoptosis via activation of caspase-3, p53 and Bax

Key words: Artemisia judaica, Antimicrobial, Anticancer, Apoptosis, Mechanism.
\end{abstract}

\section{INTRODUCTION}

For thousands of years, plants have been used to treat various human diseases and hence they considered as important sources for many bioactive compounds. The use of natural products and supplements of medicinal herbs has been increased over the past three decades with more than $80 \%$ of people worldwide depend on them for some part of primary healthcare. ${ }^{1}$

Artemisia judaica is a perennial herb that is growing abundantly in North Africa and Middle Eastern countries, ${ }^{2}$ As well in Saudi Arabia, Yemen and Egypt. ${ }^{3-5}$
It has been used traditionally in the Egyptian medicine for the treatment of gastrointestinal diseases. ${ }^{5}$ In addition; many Artemisia species have been used in Iranian traditional medicine as an anti-infectious, anti-bacterial, gastric tonic, digestive and stomachic. $^{6}$

Major medicinal effects of Artemisia that have been reported include improved vision, cardiovascular health, capillary strength, connective tissue structure, and enhanced immune system functions, as well as decreased risk of atherosclerosis,
Submission Date: 01-11-2021; Revision Date: 30-11-2021; Accepted Date: 29-12-2021.

DOI: 10.5530/ijper.56.1s.42 Correspondence:

Dr. Amr Salah Abouzied Head of Pharmaceutical Chemistry Department, College of Pharmacy, University of Hail, KSA. ORCID: 0000-0002-92023909

E-mail: as.ibrahim@uoh. edu.sa

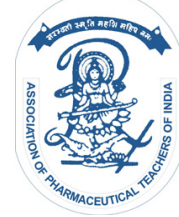

www.ijper.org 
cancer, arthritis and gastrointestinal disorders. ${ }^{7,8}$ Also, it was found that its aqueous and ethanolic extracts possess anti-diabetic effect. ${ }^{9}$

It was found that Artemisia contains sesqui-terpene lactones and other active phytochemical components. Sesqui-terpene lactones were used for their therapeutic and other properties, ${ }^{10}$ recently, monoterpenes, sesqui-terpenes, sesqui-terpene lactones, flavonoids, coumarins, sterols, poly-acetylenes have been isolated from Artemisia species. ${ }^{11}$

Isolated compounds from Artemisia judaica have exhibited antiviral, antibacterial, antifungal, and cytoprotective effects, ${ }^{12-14}$ and used for the treatment of hepatitis, cancer and menstrual-related disorders, ${ }^{15}$ Artemisia judaica showed a promising cytotoxic activity against some cancer cell lines ${ }^{16}$ which may be due to its essential oil content of thujone. ${ }^{17}$

The present study is designed to evaluate the antimicrobial and cytotoxic effect of methanolic extract of Artemisia judaica leaves and stem with mechanistic determination of its cytotoxic effect on different cell lines.

\section{MATERIALS AND METHODS}

\section{Plant Collection and Extract Preparation}

The aerial parts (Leaves and stem) of Artemisia judaica, were collected during the flowering stage from Hail region, KSA. Herbs were washed and shade dried for a week and was grinded to fine powder, then it was extracted with methanol at a ratio of $20 \mathrm{~g}$ dry powder in $200 \mathrm{ml}$ of methanol for $48 \mathrm{hr}$ using the maceration method. The liquid extract was filtered and concentrated under vacuum by using Soxhlet extraction and then stored in the dark at $4{ }^{\circ} \mathrm{C}$ until use.

\section{RESULTS AND DISCUSSION}

\section{Antimicrobial activity of Artemisia judaica stem and leaves methanolic extracts}

We investigated the antimicrobial activity of Artemisia judaica against certain microbes, of which some have not been examined before for their susceptibility to Artemisia judaica.

Artemisia judaica methanolic extract was initially screened against Gram-positive bacteria (S. aureus and B. subtilis), Gram-negative bacteria (E. coli and P. vulgaris) and fungi (A. fumigatus and C. albicans) using a qualitative disc diffusion assay and results have been summarised in Table 1.

Results showed that the methanolic extract of leaves exerted moderate antimicrobial activity against most investigated microbes except for $P$. vulgaris and $S$. aureus whereby significantly high antimicrobial activity was exerted against these two microbes with inhibition zones of $16 \mathrm{~mm}$ and $15 \mathrm{~mm}$, respectively. While methanolic extract of stem exerted weak antimicrobial activity against most investigated microbes except for $P$. vulgaris and $S$. aureus whereby significantly moderate antimicrobial activity was exerted against these two microbes with inhibition zones of $12 \mathrm{~mm}$ and $13 \mathrm{~mm}$, respectively

Further quantitative analysis of leaves and stem extracts' antimicrobial activity was performed by investigating the minimum inhibitory concentration (MIC) against microbes using broth micro-dilution assay, ${ }^{18}$ and the results were shown in Table 2 . Results of the assay showed that both leaves and stem extracts possess good antimicrobial activity against Staphylococcus aureus followed by Proteus vulgaris with MIC values of $312.5 \mu \mathrm{g} / \mathrm{ml}$ and $625 \mu \mathrm{g} / \mathrm{ml}$ for leaves' extract and $312.5 \mu \mathrm{g} / \mathrm{ml}$ and $1250 \mu \mathrm{g} / \mathrm{ml}$ for stem extract, respectively.

Table 1: Antimicrobial activity of Artemisia judaica leaves and stem methanolic extract.

\begin{tabular}{|c|c|c|c|c|c|c|}
\hline \multicolumn{7}{|c|}{ Zone of inhibition diameter $(\mathrm{mm})^{\mathrm{a}}$} \\
\hline & \multicolumn{2}{|c|}{ Gram-positive bacteria } & \multicolumn{2}{|c|}{ Gram-negative bacteria } & \multicolumn{2}{|c|}{ Fungi } \\
\hline & S. aureus & B. subtilis & E. coli & P. vulgaris & A. fumigatus & C. albicans \\
\hline $\begin{array}{l}\text { Leaves' } \\
\text { extract }\end{array}$ & $15.2 \pm 1.4$ & $7.8 \pm 0.6$ & $14.1 \pm 1.3$ & $15.9 \pm 1.54$ & $\mathrm{NA}^{\mathrm{b}}$ & $11.7 \pm 1.15$ \\
\hline Stem's extract & $12.8 \pm 0.94$ & NA & $7.5 \pm 0.91$ & $11.6 \pm 0.6$ & NA & NA \\
\hline Gentamycin & $25.1 \pm 1.63$ & $27.3 \pm 1.5$ & $29.7 \pm 1.9$ & $26.4 \pm 1.2$ & ....... & ....... \\
\hline Ketoconazole & ......... & ........ & ........ & $\ldots \ldots$. & $19.2 \pm 1.2$ & $20.8 \pm 1.4$ \\
\hline
\end{tabular}

a Zone of inhibition diameters equal to $14 \mathrm{~mm}$ and above were considered to indicate significant antimicrobial activity, $9 \mathrm{~mm}-13 \mathrm{~mm}$ were considered to indicate moderate activity, and less than $\mathrm{gmm}$ were considered to indicate weak and insignificant activity. Zone of inhibition diameters were reported as mean (Zone of inhibition diameter $\pm \mathrm{SD}$ ) of three experiments.

b NA: No activity. 
Table 2: Minimum inhibitory concentration (MIC) of Artemisia judaica leaves and stem' methanolic extract against selected bacteria and fungi.

\begin{tabular}{|c|c|c|c|c|c|c|}
\hline & Gram-positive bacteria & Gram-negative bacteria & \multicolumn{2}{c|}{ Fungi } \\
\cline { 2 - 7 } & S. aureus & B. subtilis & E. coli & P. vulgaris & A. fumigatus & C. albicans \\
\hline Leaves' extract & 312.5 & 5000 & 625 & 312.5 & NA & 1250 \\
\hline Stem's extract & 625 & NA & 10000 & 1250 & NA & NA \\
\hline Gentamycin & 9.7 & 4.8 & 4.8 & 4.8 & $\ldots \ldots$. & $\ldots \ldots$ \\
\hline Ketoconazole & $\ldots \ldots$ & $\ldots \ldots$ & $\ldots \ldots$ & $\ldots \ldots$. & 156.25 & 312.5 \\
\hline
\end{tabular}

Table 3: IC ${ }_{50}$ values of Artemisia judaica leaves and stem methanolic extract against HepG2, HCT116, A549 and MCF-7 cancer cells.

\begin{tabular}{|c|c|c|c|c|}
\hline \multicolumn{5}{|c|}{ IC $_{50}(\mu \mathrm{g} / \mathrm{ml})^{\mathrm{a}}$} \\
\hline & HepG2 & HCT116 & A549 & MCF-7 \\
\hline $\begin{array}{c}\text { Leaves } \\
\text { extract }\end{array}$ & $3.38 \pm 0.12$ & $7.06 \pm 0.65$ & $7.64 \pm 0.82$ & $7.55 \pm 0.91$ \\
\hline Stem extract & $6.84 \pm 0.69$ & $12.8 \pm 1.4$ & $27.2 \pm 2.4$ & $30.3 \pm 2.6$ \\
\hline $\begin{array}{c}\text { Vinblastine } \\
\text { sulphate }\end{array}$ & $0.88 \pm 0.24$ & $1.45 \pm 0.31$ & $7.07 \pm 0.39$ & $2.05 \pm 0.37$ \\
\hline
\end{tabular}

a $I C_{50}$ values are reported as the mean $\left(I_{50} \pm S D\right)$ of three experiments.

Cytotoxic activity of Artemisia judaica leaves and stem methanolic extract against cancer cell lines

Artemisia judaica methanolic extract decreased cancer cell viability and demonstrated selectivity towards them

The anticancer potential of Artemisia judaica was not investigated on variable cancer cell lines, therefore we decided to examine cytotoxic activity of methanolic extract of aerial parts (leaves and stem) of Artemisia judaica on different types of cancer cell lines and elucidate its mode of action

The methanolic extract of Artemisia judaica leaves and stem has been screened against HepG2, A549, HCT116 and MCF-7 cancer cell lines and the resulting $\mathrm{IC}_{50}$ values have been summarised in Table 3. Results have shown that the leaves extract exerted high cytotoxic activity across all cell lines with $\mathrm{IC}_{50}$ values close to that of vinblastine sulphate in case of HepG2 and A549 cell lines, while stem methanolic extract exerted high cytotoxic activity against HepG2, moderate cytotoxic activity against HCT116 cell lines and weak cytotoxic activity against A549 and MCF-7 cell lines

The highest cytotoxic activity was exerted by leaves extract against HepG2 cells with an $\mathrm{IC}_{50}$ value of $3.38 \mu \mathrm{g} / \mathrm{ml}$. It is also interesting to note that the leaves extract possessed cytotoxic activity similar to that of vinblastine sulphate on $\mathrm{A} 549$ cell lines with $\mathrm{IC}_{50}$ value of $7.64 \mu \mathrm{g} / \mathrm{ml}$ and $7.07 \mu \mathrm{g} / \mathrm{ml}$, respectively.
Table 4: IC $_{50}$ values of Artemisia judaica leaves and stem methanolic extract against MRC- 5 normal cells.

\begin{tabular}{|c|c|c|c|c|c|}
\hline & $I_{50}(\mu \mathrm{g} / \mathrm{ml})^{\mathrm{a}}$ & \multicolumn{4}{|c|}{ Selectivity index (SI) } \\
\hline & MRC-5 & HepG2 & HCT116 & A549 & MCF-7 \\
\hline $\begin{array}{c}\text { Leaves } \\
\text { extract }\end{array}$ & $26.6 \pm 2.3 \mu \mathrm{g} / \mathrm{ml}$ & 7.87 & 3.77 & 3.48 & 3.66 \\
\hline $\begin{array}{c}\text { Stem } \\
\text { extract }\end{array}$ & $61.1 \pm 5.2 \mu \mathrm{g} / \mathrm{ml}$ & 8.93 & 4.77 & 2.24 & 2.02 \\
\hline
\end{tabular}

a $I C_{50}$ values are reported as the mean $\left(I C_{50} \pm S D\right)$ of three experiments. $B S I=\left(I C_{50}\right.$ of $\operatorname{MRC} 5) /\left(C_{50}\right.$ of cancer cell).

The leaves and stem extracts showed more selectivity towards all cancer cell lines relative to normal, healthy MRC5 cells, with highest selectivity being demonstrated against HepG2 cells as shown in Table 4.

This high selectivity indicates that the leaves and stem extracts are expected to be less toxic towards healthy cells. These interesting results in general, and against HepG2 cells specifically, encouraged us to further investigate the mechanism of action of both leaves and stem extracts in HepG2 cancer cells.

\section{Artemisia judaica methanolic extract induced S-phase cell-cycle arrest in HepG2 cells}

The highest cytotoxic activity for the methanolic extract was demonstrated against HepG2 cells, so we wanted to further characterise the extract's bioactivity via investigating its effect on cell-cycle progression.

HepG2 cells treated with the methanolic extract of leaves and stem showed an increase in the fraction of cells in the S-phase (56.02\% and $54.08 \%$ compared to $47.13 \%$ in the untreated cells), respectively as shown in Figure 1.

Moreover, a significant increase in the fraction of cells in the pre-G1 phase was also observed after treatment with leaves and stem extracts (32.92\% and $29.59 \%$ compared to $2.37 \%$ in the untreated cells) which indicates that both leaves and stem extracts induce apoptosis in HepG2 cells. Therefore, cell-cycle analysis 

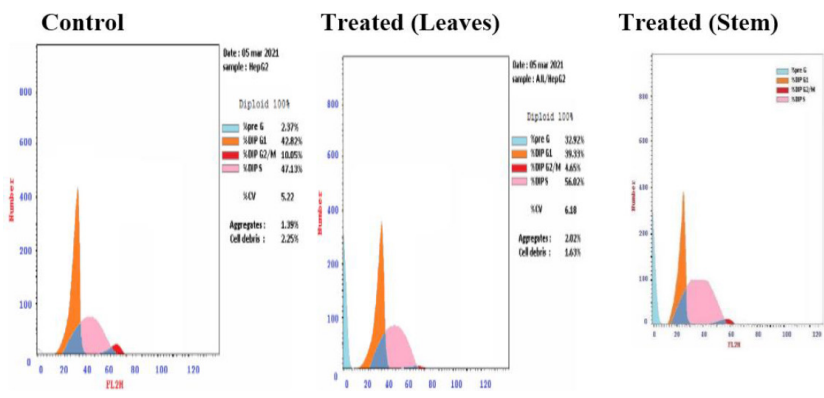

Figure 1: Representative cell-cycle histograms showing the effect of Artemisia judaica methanolic extracts on cell-cycle progression in HepG2 cells after $72 \mathrm{hr}$ of treatment at $\mathrm{IC}_{50}$ concentration.
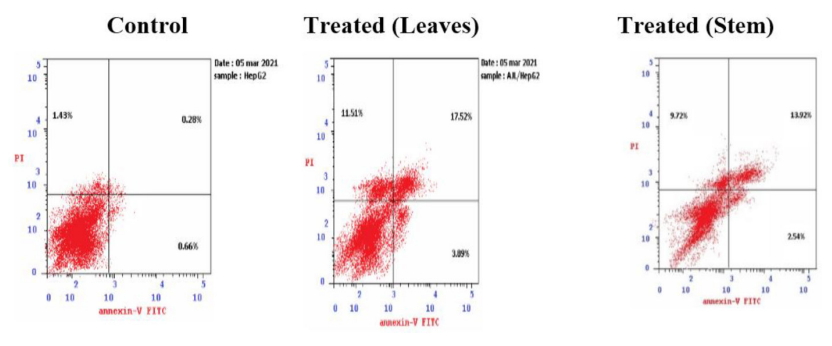

Figure 2: Representative Apoptosis quadrant plots illustrating the apoptotic effects of Artemisia judaica methanolic extracts on HepG2 cells. The cells were treated with the extract at $\mathrm{IC}_{50}$ concentration for $72 \mathrm{hr}$.

revealed that the extract induced S-phase arrest and apoptosis in HepG2 cells.

\section{Artemisia judaica leaves and stem methanolic extracts induced caspase-dependent and p53- mediated apoptosis in HepG2 cells}

Cell-cycle analysis indicated that the leaves and stem extracts induced apoptosis in HepG2 cells. Therefore, to further investigate the induction of apoptosis by the extract, an Annex in V/pro-podium iodide (PI) apoptosis assay was conducted whereby HepG2 cells were treated with leaves and stem extracts. Results of the assay showed that both extracts induced early (3.89 \% and $2.54 \%$, respectively compared to $0.66 \%$ in the untreated cells) and late (17.52 \% and $13.92 \%$, respectively compared to $0.28 \%$ in the untreated cells) as shown in Figure 2. Moreover, there was also an increase in the number of necrotic cells after treatment $(11.51 \%$ and $9.72 \%$, respectively compared to $1.43 \%$ in the untreated cells).

Therefore, it can be deduced from the apoptosis assay that the extract resulted in cancer cell death mostly via the induction of apoptosis while a less percentage of cells were found to have undergone necrosis.

Theinduction of apoptosis by leaves and stem methanolic extracts were further confirmed via investigating the expression levels of apoptosis-related proteins, such as

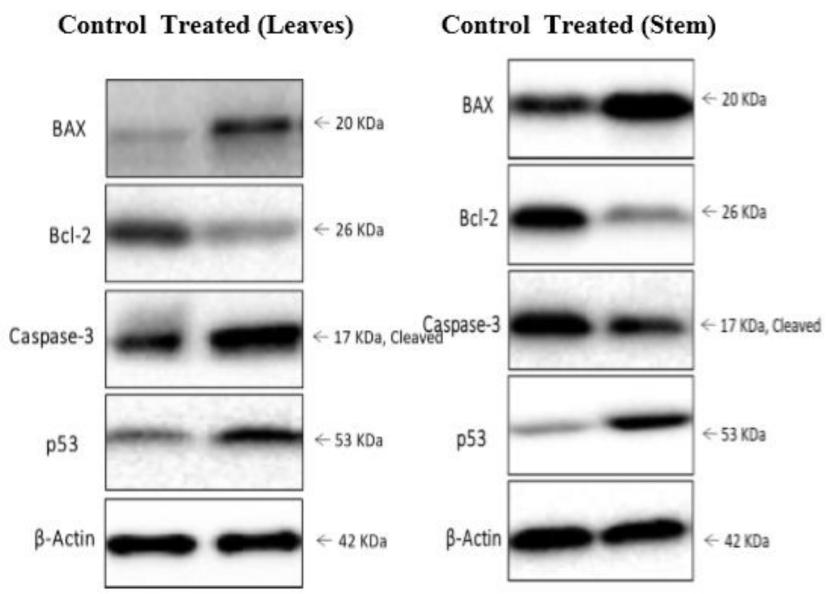

Figure 3: Western blot analysis of cleaved caspase-3, p 53, $\mathrm{Bax}$ and $\mathrm{Bcl}-2$ in HepG2 cells. Cells were treated with Artemisia judaica methanolic extracts for $72 \mathrm{hr}$ at IC concentration. $\beta$ actin was used as an internal control.

caspase-3 and p53. Activation of caspases is considered to be a hallmark of apoptosis, especially caspase-3 which is regarded as the most important executioner caspase. ${ }^{19}$ p 53 is a tumour suppressor protein that mediates several anti-proliferative processes including apoptosis, and its activation is crucial for suppressing tumorigenesis. ${ }^{20}$ Western blot analysis showed an increase in the protein expression levels of cleaved caspase-3 after treating HepG2 cells with leaves methanolic extract, while no increase was observed after treating HepG2 cells with stem methanolic extract. This indicates the induction of apoptosis in the cancer cells upon treatment with leaves extract and corroborates the data obtained from the Annexin V/PI assay as shown in Figure 3.

Moreover, p 53 expression levels were found to be enhanced following treatment with the methanolic extracts of both leaves and stem which might indicate that the induced apoptosis is probably mediated via $\mathrm{p} 53$. Therefore, Artemisia judaica leaves methanolic extract was found to cause cell death via activating caspase-3 and p53 in HepG2 cells, while stem extract was found to cause cell death via activating only p53 in HepG2 cells.

Bax is a pro-apoptotic protein that is a primary target of p53 and is responsible for caspase activation during apoptosis, however, the pro-apoptotic effects of $\mathrm{Bax}$ are suppressed by the anti-apoptotic protein Bcl-2.21,22 Therefore, investigating these proteins is supposed to provide further insight into the apoptosis mechanism triggered by leaves and stem extracts. Western blot analysis revealed that the methanolic extracts of leaves and stem increased the protein expression level of Bax but reduced the expression level of Bcl-2 in HepG2 cells as shown in Figure 3. This confirmed the pro-apoptotic 
effect of both extracts and corroborates the results of the other apoptosis-related assays

In summary, leaves extract induced apoptosis via modulation of $\mathrm{p} 53$, caspase- 3 and $\mathrm{Bax} / \mathrm{Bcl}-2$, while that of stem-induced apoptosis via modulation of p53 and $\mathrm{Bax} / \mathrm{Bcl}-2$ only.

\section{CONCLUSION}

The current research involved assessing the antimicrobial and cytotoxic activity of Artemisia judaica leaves and stem methanolic extracts in greater details. The extracts were found to possess good antimicrobial activity against Staphylococcus aureus and Proteus vulgaris. Moreover, the extracts exerted their highest cytotoxic activity against HepG2 cells and were found to possess high selectivity against these cells. Further studies showed that the extracts caused caspase-dependent, p 53-mediated apoptosis in HepG2 cells and resulted in S-phase cell cycle arrest. This study demonstrated the antimicrobial and anticancer potential of Artemisia judaica methanolic extracts and provided a better understanding about extracts' anticancer mode of action.

\section{ACKNOWLEDGEMENT}

This research has been funded by Scientific Research Deanship at University of Hail, Saudi Arabia through Project number: RG-20118.

\section{CONFLICT OF INTEREST}

The authors declare that there are no conflicts of interest.

\section{ABBREVIATIONS}

MIC: Minimum Inhibitory Concentration; HepG2: Human Liver Cancer Cell Line; HCT-116: Human Colorectal Carcinoma Cell Line; MCF-7: Breast Cancer Cell Line; A-549: Adenocarcinomic Human Alveolar Basal Epithelial Cells; MRC-5: Medical Research Council Cell Strain 5 which is diploid cell line; $\mathbf{I C}_{50}$ : Half-Maximal Inhibitory Concentration; p53: Tumour suppressor protein; Bax: Apoptosis Regulator Protein; S-Phase: Synthesis Phase

\section{REFERENCES}

1. Ekor M. The growing use of herbal medicines: Issues relating to adverse reactions and challenges in monitoring safety. Front Pharmacol. 2014;4(4):177. doi: 10.3389/fphar.2013.00177, PMID 24454289.
2. Alzweiri M, Alrawashdeh IM, Bardaweel SK. The development and application of novel IR and NMR-based model for the evaluation of carminative effect of Artemisia judaica L. essential oil. Int J Anal Chem. 2014 Dec 29;2014:627038. doi: 10.1155/2014/627038, PMID 25614741.

3. Abad MJ, Bedoya LM, Apaza L, Bermejo P. The Artemisia L. genus: A review of bioactive essential oils. Molecules. 2012 Mar 2;17(3):2542-66. doi: 10.3390/molecules17032542, PMID 22388966.

4. Chhetri BK, Al-Sokari SS, Setzer WN, Ali NAA. Essential oil composition of Artemisia abyssinica from three habitats in Yem-en. Am J Essent Oeil Nat Prod. 2015 Apr;2(3):28-30.

5. Liu CZ, Murch SJ, EL-Demerdash M, Saxena PK. Artemisia judaica L.: micropropagation and antioxidant activity. J Biotechnol. 2004;110(1):63-71. doi: 10.1016/j.jbiotec.2004.01.011, PMID 15099906.

6. Nezhadali A, Parsa M. Study of the Volatile Compounds in Artemisia sagebrush from Iran using HS/SPME/GC/MS. IJESD:287-9. doi: 10.7763/ IJESD.2010.V1.56.

7. Khafagy SM, El-Din AAS, Jakupovic J, Zdero C, Bohlmann F. Glaucolidelike sesquiterpene lactones from Artemisia judaica. Phytochemistry. 1988;27(4):1125-28. doi: 10.1016/0031-9422(88)80287-5.

8. Abdalla SS, Abu Zarga $\mathrm{MH}$. Effects of cirsimaritin, a flavone isolated from Artemisia judaica, on isolated guinea-pig ileum. Planta Med. 1987 Aug;53(4):322-4. doi: 10.1055/s-2006-962727, PMID 3671552.

9. Nofal SM, Mahmoud SS, Ramadan A, Soliman GA, Fawzy R. Anti-diabetic effects of Artemisia Jjudaica extracts. Res J Med Med Sci. 2009 Jan;4(1):42-8.

10. Giordano OS, Guerreiro E, Pestchanker MJ, Guzman J, Pastor D, Guardia T. The gastric cytoprotective effect of several sesquiterpene lactones. J Nat Prod. 1990 Jul;Aug(4):803-9. doi: 10.1021/np50070a004, PMID 2095374.

11. Rustaiyan A, Ezzatzadeh E. Sesquiterpene lactones and pen-ta-methoxylated flavone from Artemisia kulbadica. Asian J Chem. 2011 Apr;23(4):1774--76.

12. Abdelgaleil SA, Abbassy MA, Belal AS, Abdel Rasoul MA. Bioactivity of two major constituents isolated from the essential oil of Artemisia judaica L. Bioresour Technol. 2008 Sep;99(13):5947-50. doi: 10.1016/j. biortech.2007.10.043, PMID 18054484.

13. Bora KS, Sharma A. The genus Artemisia: A comprehensive review. Pharm Biol. 2011 Jan;49(1):101-9. doi: 10.3109/13880209.2010.497815, PMID 20681755.

14. Abood S, Eichelbaum S, Mustafi S, Veisaga ML, López LA, Barbieri M. Biomedical Properties and Origins of Sesquiterpene Lactones, with a Focus on Dehydroleucodine. Nat Prod Commun. 2017 Jun;12(6):995-1005. doi: 10.1177/1934578X1701200638.

15. Nigam M, Atanassova M, Mishra AP, Pezzani R, Devkota HR, Plygun S, et al. Bioactive Compounds and Health Benefits of Artemisia Sspecies: [Rreview]. Nat Prod Commun. 2019 Jul;24(15):1-17.

16. Nasr FA, Noman OM, Mothana RA, Alqahtani AS, Al-Mishari AAFahd AN, et al. Cytotoxic, antimicrobial and antioxidant activities and phytochemical analysis of Artemisia judaica and A. sieberi in Saudi Arabia. Afr J Pharm Pharmacol. 2020 Sep; 14(8): 278-84. doi: 10.5897/AJPP2020.5175.

17. Elansary HO, Abdelgaleil SAM, Mahmoud EA, Yessoufou K, Elhindi K, El-Hendawy S. Effective antioxidant, antimicrobial and anticancer activities of essential oils of horticultural aromatic crops in northern Egypt. BMC Complement Altern Med. 2018 Jul;18(1):214. doi: 10.1186/s12906-018-2262-1, PMID 30005652.

18. Espinel-Ingroff A. Comparison of the E-test with the NCCLS M38-P method for antifungal susceptibility testing of common and emerging pathogenic filamentous fungi. J Clin Microbiol. 2001 Apr;39(4):1360-67. doi: 10.1128/ JCM.39.4.1360-1367.2001, PMID 11283057.

19. Gong L, Tang Y, An R, Lin M, Chen L, Du J. RTN1-C mediates cerebral ischemia/reperfusion injury via ER stress and mitochondria-associated apoptosis pathways. Cell Death Dis. 2017 Oct;8(10):e3080. doi: 10.1038/ cddis.2017.465, PMID 28981095.

20. Khazaei S, Abdul Hamid R, Ramachandran V, Mohd EN, Pandurangan AK, Danazadeh F, et al. Cytotoxicity and Pro-apoptotic Effects of Allium atroviolaceum Flower Extract by Modulating Cell Cycle Arrest and CaspaseDependent and p53-Independent Pathway in Breast Cancer Cell Lines. Evid Based Complement Alternat Med. 2017 Nov:1-16.

21. Chen CY, Liu TZ, Tseng WC, Lu FJ, Hung RP, Chen CH, et al. (-)-Anonaine induces apoptosis through Bax- and caspase-dependent pathways in human 
cervical cancer (HeLa) cells. Food Chem Toxicol. 2008 Aug;46(8):2694-702. doi: 10.1016/j.fct.2008.04.024, PMID 18524447.

22. Al-Salman HNK, Ali ET, Jabir M, Sulaiman GM, Al-Jadaan SAS. 2-Benzhydrylsulfinyl-N-hydroxyacetamide- $\mathrm{Na}$ extracted from Figure as a novel cytotoxic and apoptosis inducer in SKOV-3 and AMJ-13 cell lines via P53 and caspase-8 pathway. Eur Food Res Technol. 2020 May;246(8):1591-608. doi: 10.1007/s00217-020-03515-x.
PICTORIAL ABSTRACT

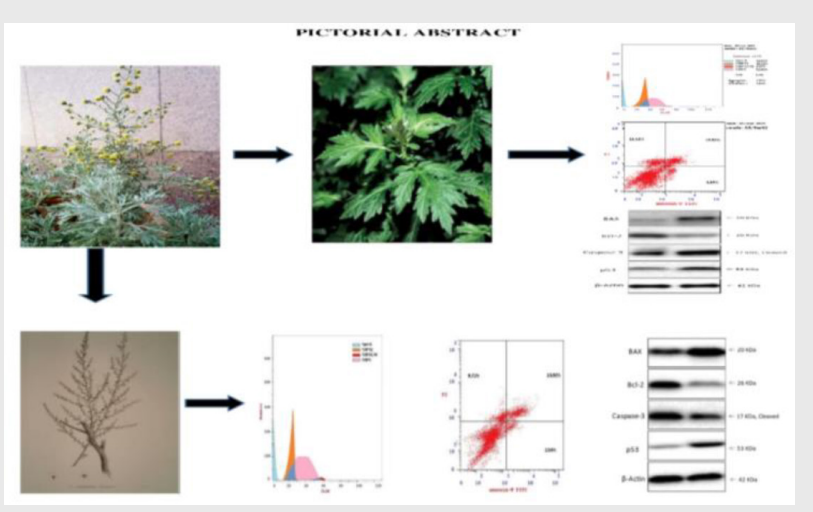

\section{SUMMARY}

Methanolic extracts of Artemisia judaica leaves and stem were screened for their antimicrobial and cytotoxic activities and it was found that they possess good antimicrobial activity against Staphyllcoccus aureus and Proteus vulgaris, while they possess high cytotoxic activity against HepG2 cells by caspase-dependent, p 53-mediated apoptosis mechanism.

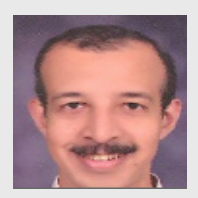

Dr. Kareem Younes, is presently working as an assistant professor in Pharmaceutical Chemistry Department, College of Pharmacy, University of Hail. He completed his $\mathrm{Ph}$. D. from Cairo University in the field of Pharmaceutical Analytical Chemistry. He has published several research articles in national and international journals of repute

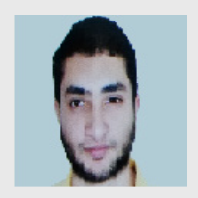

Dr. Mohamed Bin is presently working as an assistant professor in Pharmaceutical Chemistry Department, College of Pharmacy, University of Hail. He completed his Ph. D.in the field of Medicinal Chemistry.
Dr. Amr Salah Abouzied he completed his Ph. D. from Cairo University in the field of Pharmaceutical Organic Chemistry $\mathrm{He}$ is currently Assistant Professor and Head of Pharmaceutical Chemistry Department, College of Pharmacy, University of Hail, With an experience of more than seventeen years in academic teaching and scientific research, He have authored many peer-reviewed scholarly articles published in top international journals. His research interest is the isolation characterization, computational and Molecular Simulations of macromolecules like proteins along with design and synthesis of organic molecules as therapeutic candidates.

Dr. Rahamat Unissa, Assistant Professor in the Department of Pharmaceutics, University of Hail.Doctorate from Jawaharlal Nehru Technological University, Hyderabad, India. Have five years of research and academic experience. Guided seven research projects and author of four books.

Afnan Abdulkarem Almarshdi, College of Pharmacy, University of Hail. Internship at King Abdulaziz Medical City (MNG-HA) - Jeddah and King Saud University Medical City - Riyadh, Kingdom of Saudi Arabia

Fai Mutaz Alharbi, College of Pharmcy, University of Hail. Internship at King Saud University Medical City, King Fahad Medical City - Riyadh, Kingdom of Saudi Arabia.

Sulafa Salem Alenzi, College of Pharmcy, University of Hail. Internship at King Abdulaziz Medical City (MNG-HA) and king Fahd armed forces hospital (KFAFH) - Jeddah, Kingdom of Saudi Arabia.

Bayan Naef albsher, Pharmacy Student, University of Hail, Kingdom of Saudi Arabia

Cite this article: Younes KM, Break MKB, Syed RU, Almarshdi AA, Alharbi FM, Alenzi SS, Albsher BN, Abouzied AS. In-vitro Evaluation of Anti-microbial and Cytotoxic Activity of Artemisia judaica Leaves and Stem Extracts via Induction of Caspase Dependent Apoptosis. Indian J of Pharmaceutical Education and Research. 2022;56(1s):s52-s57. 